\title{
Commentary: Exogenous
} Testosterone Rapidly Increases Aggressive Behavior in Dominant and Impulsive Men

\author{
Leo Sher ${ }^{1,2 *+}$ \\ ${ }^{1}$ James J. Peters Veterans' Administration Medical Center, Bronx, NY, USA, ${ }^{2}$ Icahn School of Medicine at Mount Sinai, \\ New York, NY, USA
}

Keywords: men, testosterone, aggression, dominance, suicide

\section{A commentary on}

\section{OPEN ACCESS}

Edited by:

Frederick Robert Carrick,

Bedfordshire Centre for Mental Health Research in Association with

University of Cambridge, UK

Reviewed by:

Richard Rowe,

University of Sheffield, UK

Luigi Janiri,

Università Cattolica

del Sacro Cuore, Italy

*Correspondence:

Leo Sher

drleosher@gmail.com

${ }^{+} D r$. Leo Sher is the Chair of the World Federation of Societies of Biological Psychiatry (WFSBP) Task

Force on Men's Mental Health.

Specialty section: This article was submitted to Child Health and Human Development, a section of the journal

Frontiers in Public Health

Received: 29 August 2016 Accepted: 29 September 2016 Published: 12 October 2016

Citation:

Sher L (2016) Commentary: Exogenous Testosterone Rapidly Increases Aggressive Behavior in

Dominant and Impulsive Men.

Front. Public Health 4:229. doi: 10.3389/fpubh.2016.00229
Exogenous Testosterone Rapidly Increases Aggressive Behavior in Dominant and Impulsive Men by Carré JM, Geniole SN, Ortiz TL, Bird BM, Videto A, Bonin PL. Biol Psychiatry (2016). doi:10.1016/j. biopsych.2016.06.009

I read with interest a research report, "Exogenous testosterone rapidly increases aggressive behavior in dominant and impulsive men" by Carré et al. that was recently published in Biological Psychiatry (1). Healthy adult men were administered either testosterone or placebo, and then engaged in a decision-making game that assesses aggressive behavior in response to social provocation. The researchers also examined the extent to which testosterone influence on aggressive behavior depends on variability in trait dominance and/or trait self-control. The authors observed that exogenous testosterone on its own did not modulate aggressive behavior. However, they found that testosterone can quickly (within $60 \mathrm{~min}$ ) potentiate aggressive behavior among men with dominant or impulsive personality styles. More specifically, testosterone increased aggressive behavior, but only among men scoring high in trait dominance or men scoring low in trait self-control. There was no effect of testosterone on aggressive behavior in men scoring low in trait dominance or high in trait self-control.

The observation by Carré et al. (1) is consistent with our case report published in 2013 (2). We reported a case of a middle-age man with a history of bipolar disorder with psychotic features, substance use disorder, and aggressive behavior who became violent some hours after receiving a testosterone injection and hit his wife in the abdominal area which led to an internal bleeding and resulted in her death. He admitted to the police to pushing his wife down on the ground and kicking her in the stomach. It is difficult to establish a clear relation between the testosterone administration and the murder in this case. However, the testosterone administration possibly contributed to homicide.

The observation by Carré et al. (1) may shed some light on the relationships between testosterone and suicidal behavior. Several studies suggested that testosterone may be involved in the pathophysiology of suicidal behavior (3-7) while at least two studies did not support this assertion $(8,9)$. It has been proposed that there are substantial similarities between aggression against the self and aggression against others, based on the clinical and epidemiological findings that some suicide attempters may share personality traits with violent criminals (10). An association between aggression and suicidal behavior has been observed by multiple researchers (11-15). For example, it has been shown that high aggression predicts suicidal acts (11). We have also shown that the higher prevalence of suicide attempters among depressed patients with a history of alcoholism 
compared to depressed patients without a history of alcoholism was related to higher aggression scores in the group with alcoholism (12). Thus, men who become impulsive-aggressive when the testosterone levels are higher may also have a tendency to commit a suicidal act when the testosterone concentrations are higher, i.e., these men may be potential suicide attempters. Identification of such men may help to prevent suicide attempts.

\section{REFERENCES}

1. Carré JM, Geniole SN, Ortiz TL, Bird BM, Videto A, Bonin PL. Exogenous testosterone rapidly increases aggressive behavior in dominant and impulsive men. Biol Psychiatry (2016). doi:10.1016/j.biopsych.2016.06.009

2. Sher L, Landers S. Bipolar disorder, testosterone administration, and homicide: a case report. Int J Psychiatry Clin Pract (2014) 18(3):215-6. doi:10.310 9/13651501.2014.894075

3. Tripodianakis J, Markianos M, Rouvali O, Istikoglou C. Gonadal axis hormones in psychiatric male patients after a suicide attempt. Eur Arch Psychiatry Clin Neurosci (2007) 257:135-9. doi:10.1007/s00406-006-0686-y

4. Markianos M, Tripodianakis J, Istikoglou C, Rouvali O, Christopoulos M, Papageorgopoulos $\mathrm{P}$, et al. Suicide attempt by jumping: a study of gonadal axis hormones in male suicide attempters versus men who fell by accident. Psychiatry Res (2009) 170:82-5. doi:10.1016/j.psychres.2008.08.001

5. Sher L, Grunebaum MF, Sullivan GM, Burke AK, Cooper TB, Mann JJ, et al. Testosterone levels in suicide attempters with bipolar disorder. J Psychiatr Res (2012) 46:1267-71. doi:10.1016/j.jpsychires.2012.06.016

6. Sher L, Grunebaum MF, Sullivan GM, Burke AK, Cooper TB, Mann JJ, et al. Association of testosterone levels and future suicide attempts in females with bipolar disorder. J Affect Disord (2014) 166:98-102. doi:10.1016/ j.jad.2014.04.068

7. Zhang J, Jia CX, Wang LL. Testosterone differs between suicide attempters and community controls in men and women of China. Physiol Behav (2015) 141:40-5. doi:10.1016/j.physbeh.2015.01.004

8. Butterfield MI, Stechuchak KM, Connor KM, Davidson JR, Wang C, MacKuen CL, et al. Neuroactive steroids and suicidality in posttraumatic stress disorder. Am J Psychiatry (2005) 162:380-2. doi:10.1176/appi.ajp.162.2.380

9. Perez-Rodriguez MM, Lopez-Castroman J, Martinez-Vigo M, DiazSastre C, Ceverino A, Núñez-Beltrán A, et al. Lack of association between testosterone and suicide attempts. Neuropsychobiology (2011) 63:125-30. doi:10.1159/000318085
This may be an interesting and important new avenue in suicide prevention work.

\section{AUTHOR CONTRIBUTIONS}

The author confirms being the sole contributor of this work and approved it for publication.

10. Engström G, Persson B, Levander S. Temperament traits in male suicide attempters and violent offenders. Eur Psychiatry (1999) 14(5):278-83. doi:10.1016/S0924-9338(99)00170-4

11. Oquendo MA, Galfalvy H, Russo S, Ellis SP, Grunebaum MF, Burke A, et al. Prospective study of clinical predictors of suicidal acts after a major depressive episode in patients with major depressive disorder or bipolar disorder. Am J Psychiatry (2004) 161(8):1433-41. doi:10.1176/appi.ajp.161.8.1433

12. Sher L, Oquendo MA, Galfalvy HC, Grunebaum MF, Burke AK, Zalsman G, et al. The relationship of aggression to suicidal behavior in depressed patients with a history of alcoholism. Addict Behav (2005) 30(6):1144-53. doi:10.1016/ j.addbeh.2004.12.001

13. Swogger MT, Van Orden KA, Conner KR. The relationship of outwardlydirected aggression to suicidal ideation and suicide attempts across two high-risk samples. Psychol Violence (2014) 4(2):184-95. doi:10.1037/ a0033212

14. Wang L, He CZ, Yu YM, Qiu XH, Yang XX, Qiao ZX, et al. Associations between impulsivity, aggression, and suicide in Chinese college students. BMC Public Health (2014) 14:551. doi:10.1186/1471-2458-14-551

15. Gvion Y, Apter A. Aggression, impulsivity, and suicide behavior: a review of the literature. Arch Suicide Res (2011) 15(2):93-112. doi:10.1080/13811118.2 011.565265

Conflict of Interest Statement: The author declares that the research was conducted in the absence of any commercial or financial relationships that could be construed as a potential conflict of interest.

Copyright (C) 2016 Sher. This is an open-access article distributed under the terms of the Creative Commons Attribution License (CC BY). The use, distribution or reproduction in other forums is permitted, provided the original author(s) or licensor are credited and that the original publication in this journal is cited, in accordance with accepted academic practice. No use, distribution or reproduction is permitted which does not comply with these terms. 